\author{
Jacek Perlin*, Agnieszka Mielczarek*** \\ ${ }^{*}$ Uniwersytet Warszawski \\ Instytut Studiów Iberyjskich i Iberoamerykańskich \\ ** Uniwersytet im. Adama Mickiewicza w Poznaniu \\ Studium Języka i Kultury Polskiej dla Cudzoziemców
}

\title{
Kategoria płci w języku polskim
}

Słowa klucze: rodzaj gramatyczny w języku polskim, kategoria płci w języku polskim

Ke y w ord s: grammatical gender in Polish, gender category in Polish

Wyrazista kategoria wyłącznie płci, z całą pewnością nie tzw. rodzaju, występuje w językach Europy tylko w baskijskim ${ }^{1}$ (choć nie we wszystkich jego dialektach). W języku tym, zupełnie bezrodzajowym z naszego punktu widzenia, rzeczowniki, przymiotniki, liczebniki i zaimki osobowe czy dzierżawcze mają zawsze identyczną formę, odmieniając się jedynie przez przypadki i liczbę. Natomiast kategoria płci jest kategorią czasownika (odpowiednie morfemy są w formie werbalnej), choć odnosi się do osoby rozmówcy (tzw. zjawisko morfemów nie na swoim miejscu), z którym jesteśmy na ty. Morfem płci rozmówcy występuje jedynie w sytuacjach, gdy wobec rozmówcy używa się poufałego zaimka osobowego $h i$ 'ty'. Morfem płci pojawia się, gdy odbiorca komunikatu jest podmiotem lub dopełnieniem czasownika

\footnotetext{
1 Fakty baskijskie za: Burgos Echagüe (2012).
} 
przechodniego oraz gdy do jego osoby w żadnej postaci nie odnosi się użyty czasownik. Nie wyraża się płci, gdy odbiorca komunikatu jest podmiotem zdania z czasownikiem nieprzechodnim:

Ikusten duk 'widzisz' (przy zwracaniu się do osoby płci męskiej) - Ikusten dun 'widzisz' (przy zwracaniu się do osoby płci żeńskiej).

Eman diat 'dałem/dałam ci to'(przy zwracaniu się do osoby płci męskiej) - Eman dinat 'dałem/dałam ci to' (przy zwracaniu się do osoby płci żeńskiej).

Etorri nauk 'przyszedłem/przyszłam' (przy zwracaniu się do osoby płci męskiej) - Etorri naun 'przyszedłem/przyszłam' (przy zwracaniu się do osoby płci żeńskiej).

Berak egin dik 'on/a to zrobił/a' (przy zwracaniu się do osoby płci męskiej) - Berak egin din (przy zwracaniu się do osoby płci żeńskiej).

Ale: Hi Euskalduna haiz 'ty jesteś Baskiem/Baskijką', bez rozróżnienia płci.

Kategoria rodzaju, charakterystyczna przede wszystkim dla języków indoeuropejskich (także afroazjatyckich), wykazuje wprawdzie silny związek $\mathrm{z}$ płcią, ale nie jest to kategoria wyłącznie płci². W językach mających tzw. rodzaj męski i żeński (niektóre, jak niderlandzki i szwedzki, mają nijaki i nienijaki, czyli neutrum i utrum; inne, jak polski, mają jeszcze nijaki oraz podrodzaje męskiego, np. męskoosobowy; rosyjski ma podrodzaj żywotny dla wszystkich rodzajów) ogólnie jest tak, że rzeczowniki mają przypisany im rodzaj - niektóre męski, inne żeński (kategoria selektywna), a przymiotniki i inne określające części mowy odmieniają się przez rodzaj (kategoria modulująca), wchodząc z rzeczownikami w związek składni zgody. Określenie rodzaj męski i żeński ma podstawy statystyczne: większość rzeczowników określających ludzi lub zwierzęta jest rodzaju męskiego, jeśli odnosi się do mężczyzn/samców, i żeńskiego, jeśli odnosi się do kobiet/samic. Nie jest to jednak ściśle kategoria płci z dwóch powodów: po pierwsze rodzaj męski i żeński mają też rzeczowniki oznaczające przedmioty i pojęcia abstrakcyjne; po drugie od statystycznej reguły rodzaj męski - płeć męska, rodzaj żeński płeć żeńska zdarzają się wyjątki, np. we francuskim rodzaju męskiego jest le

2 Bogaty przegląd literatury, głównie anglojęzycznej, na temat rodzaju gramatycznego znajduje się w artykule Koziarskiego i Krysiaka (2012). 
professeur - profesor/ka, rodzaju żeńskiego la recrue - 'rekrut'. W polskim jest żeńska ciota i męskie babsztyl, babon, wamp, podlotek.

We francuskim istnieje kategoria rodzaju rzeczownika, która obowiązuje w grupie nominalnej na normalnych zasadach uzgodnienia, jednak w orzeczniku obowiązuje zawsze kategoria płci. Np. Notre nouveau professeur est très belle, dosł. 'nasz nowy profesor jest bardzo ładna', albo Cette recrue n'est pas con, dosł. 'ta rekruta nie jest głupi'.

Celem tego artykułu jest pokazanie, że kategoria płci występuje również w języku polskim, jednak na zupełnie innych zasadach niż w odmiennym typologicznie baskijskim i nieco innych niż w przytoczonych przykładach francuskich ${ }^{3}$.

W polskim istnieje kategoria rodzaju, częściowo związana semantycznie z płcią $\mathrm{i}$ - tak jak w innych językach europejskich - w niektórych klasach rzeczowników niezwiązana z nią w ogóle (zob. Bańczerowski i in. 1982: 217). Przy tym zupełnie inaczej rzecz się ma w liczbie pojedynczej i w mnogiej. Kategoria rodzaju występuje jako selektywna w rzeczownikach (niektóre można przy tym uznać za odmieniające się przez rodzaj, jak lekarz - lekar$k a$ ), a modulująca w przymiotnikach, liczebnikach, zaimkach i czasownikach. W polskim rodzajów można wyróżnić wyjątkowo dużo (zob. Mańczak 1956; Saloni 1976, 1988; Kucała 1978; Laskowski 1999; Zaron 2001, 2004, Stefańczyk 2007). Jeżeli za kryterium weźmiemy kongruencję z przymiotnikami, otrzymamy rodzaj żeński, nijaki, męski rzeczowy, męski żywotny, męski osobowy i ewentualnie pluralia tantum, które dodatkowo można podzielić na męskoosobowe i niemęskoosobowe (widzę tych państwa/widzę te zwłoki). Jeżeli weźmie się pod uwagę łączliwość z liczebnikami, otrzymamy więcej jeszcze rodzajów, gdyż mamy $d$ wa wiadra, ale $d$ woje $d z i e c i, d$ wie pary nożyczek i dwoje drzwi lub skrzypiec ${ }^{4}$.

Osoby lub zwierzęta, czyli istoty mające płeć, mogą być określane przez rzeczowniki rodzaju męskoosobowego, męskożywotnego, żeńskiego i nijakiego, a nawet pluralia tantum, a więc przez wszystkie rodzaje z wyjątkiem męskorzeczowego. Rzeczowniki te można podzielić na wskazujące lub nie na określoną płeć. Przykłady z pierwszej grupy to chtopiec (rodzaj męskoosobowy, płeć męska), chłopak (rodzaj męskożywotny, płeć męska), siostra

3 O relacjach płeć a język zob. Pycia (2011), a o relacjach płeć a rodzaj gramatyczny zob. Nowosad-Bakalarczyk (2009).

4 Tradycyjnie różnice te nie są uważane za związane z kategorią rodzaju. 
(rodzaj żeński, płeć żeńska), dziewczę (rodzaj nijaki, płeć żeńska), pacholę (rodzaj nijaki, płeć męska), babsztyl (rodzaj męskożywotny, płeć żeńska), ciota (rodzaj żeński, płeć męska), państwo, wujostwo, stryjostwo, szwagrostwo (pluralia tantum męskoosobowe), matżeństwo (rodzaj nijaki, para płci męskiej i żeńskiej - przynajmniej w znaczeniu tradycyjnym).

Pewna grupa rzeczowników wskazuje na osobę bez rozróżniania płci. Są to np. osoba, ofiara, indywiduum, geniusz, dziecko, dziecie, niemowle, szczenię, ciele, źrebak czy duch (zakładamy, że duch ma, a przynajmniej miał kiedyś, płeć). W zasadzie nie denotuje płci męski rzeczownik człowiek, choć mówiąc o kobiecie, używa się go rzadko. Nie denotuje płci trup, który - co zabawne - ma rodzaj męskożywotny (nie męskoosobowy). Spośród pluraliów tantum niemęskoosobowych jest bodajże jeden denotujący osobę bez wskazania płci: zwłoki. Znakomita większość nazw zwierząt należy do kategorii epicenów i nie określa płci (mysz, gawron, kawka, leniwiec, nosorożec). Istotnym wyjątkiem są nazwy zwierząt udomowionych kon - klacz), łownych (jeleń- tania) i niektórych innych (lew - lwica, wilk-wilczyca).

Rzeczowniki typu ekscelencja, eminencja, magnificencja, (wasza) wysokość, światobliwość, miłość też nie określają płci (poza światobliwościq i eminencja w Kościele Katolickim (ale to z przyczyn uwarunkowań historycznych, a nie morfologii) i mają zawsze rodzaj żeński z punktu widzenia łączliwości z przymiotnikami (wasza miłość, szara eminencja). Osobną kwestią są collectiva. Występują one zasadniczo w liczbie pojedynczej (niektóre są singularia tantum). Chodzi o rzeczowniki typu szlachta, arystokracja, generalicja, nauczycielstwo, bractwo, tłuszcza, pospólstwo. Wszystkie one oznaczają grupy osób, na ogół płciowo mieszane.

Szczególnym przypadkiem jest rzeczownik rodzeństwo, oznaczający najczęściej grupę płciowo mieszaną (jak się ma samych braci lub same siostry, rzadko się powie o nich moje rodzeństwo), jednak jest to faktycznie rzeczownik nieokreślony ani pod względem liczby, ani płci. Na pytanie masz rodzeństwo? można odpowiedzieć: - tak, jednego brata; tak, jednq siostrę, jaki i tak, dwóch braci i dwie siostry.

Rzeczownikami nieokreślającymi płci, a jednocześnie dwurodzajowymi, są np. profesor, doktor, magister, dyrektor, minister, neurobiolog, Nowak, Adamczyk, czyli nazwy funkcji, tytułów i zawodów oraz nazwiska. W postaci mianownika liczby pojedynczej są one jednakowe w obu rodzajach. W innych formach rodzaj ujawnia się w ten sposób, że formy żeńskie pozostają 
nieodmienne, a męskie przybierają końcówki; to pismo dla (pani) dyrektor / to pismo dla dyrektora, powiedziat to Adamczykowi / powiedziat to Adam$c z y k$. Jednocześnie formy rodzaju męskiego nie wskazują na płeć męską, choć żeńskie tak. Nowak jest wybitnq neurobiolog to zdanie o kobiecie, podczas gdy Nowak jest wybitnym neurobiologiem nie mówi nic o płci podmiotu.

Wszystkie rzeczowniki określające funkcję, zawód, wykonawcę czynności, narodowość itp., mające odpowiedniki żeńskie, w użyciu gatunkowym stosowane w formie męskiej, nie konotuja płci, np. w sformułowaniach: nasz klient nasz pan, madry Polak po szkodzie, każdy uczestnik, członek honorowy towarzystwa, przechodzacy przez jezdnie, podpis wynajmujacego, użytkownik mieszkania, kierujacy pojazdem jednośladowym może być mowa zarówno o mężczyźnie, jak o kobiecie.

Teoretycznie dwurodzajowe są oferma, sierota, łajza, łazęga, ciamajda, niedojda, łamaga, pokraka, niezdara, gaduła, kanalia. Tak mówi norma (Markowski 2012, zob. też hasło Rodzaj gramatyczny w Encyklopedii języka polskiego, Urbańczyk 1991: 286), jednak jest to norma papierowa. W normalnym, codziennym uzusie wszystkie one są wyłącznie rodzaju żeńskiego i nie denotują płci. Osobiście słyszeliśmy setki razy sformułowania w rodzaju ta sierota zarzygana, moja ty biedna sierotko, moja nieszczęsna oferma, ty wstrętna łajzo, ale z niego obrzydliwa niezdara, wredna kanalia, skierowane do mężczyzn lub mówiące o mężczyznach i nigdy, w całym naszym życiu, żeby ktoś powiedział (powiedział, nie napisał po długiej refleksji) ten biedny sierota ${ }^{5}$.

Spora grupa rzeczowników jednorodzajowych może odnosić się do określania osób obu płci, choć nie jest to ich pierwsze znaczenie. Wszystkie one są stylistycznie nacechowane, prawie zawsze (choć jest kilka wyjątków) negatywnie. Przykłady: potwór, monstrum, szmata, ściera, bydlę, bestia, dupa wołowa, gnida, ścierwo, gówno, cudo, paskudztwo, zjawisko, skarb, świnia, matpa, papuga ${ }^{6}$, pijawka, menda, śnięta ryba, zaraza, cholera, charakterek. Ciekawym przypadkiem jest świnia, której można użyć tak do kobiet, jak do mężczyzn (ten facet to świnia), podczas gdy np. krowa powie się raczej tylko o kobiecie. Są też rzeczowniki, które służą do nazywania osób tylko jednej, określonej płci, np. cipa, suka, pedat, kutas. Mają one z reguły rodzaj odpo-

5 Z tej grupy może jedynie kaleka i łachmyta bywają w codziennym użyciu dwurodzajowe.

${ }^{6}$ Papuga w znaczeniu 'adwokat' może mieć rodzaj męski. 
wiadający płci, choć męskorodzajowych wieloryb i kaszalot używa się chyba tylko do określania otyłych kobiet.

Rodzaju męskiego są wreszcie nieokreślające płci zaimki kto, ktoś i nikt: Kto to byt? Ktoś na ciebie czekat. Nikt nie jest głodny? Uwikłane w płeć są też nijakie zaimki które, któreś, żadne, każde w konstrukcjach typu żadne $z$ was, któreś z nich. Komunikują one, że chodzi o grupę płciowo mieszaną.

Podsumowując sprawę rodzaju w liczbie pojedynczej i w pluraliach tantum: można sformułować bardzo wiele zdań, które nie określają płci omawianego obiektu, gdyż rzeczownik albo jest dwurodzajowy, albo użyty jest generycznie, albo wreszcie odnosi się, niezależnie od rodzaju, do obu płci, np.: Klient ma zawsze rację. Kowalczyk nie ma racji. Osobie duchownej to nie przystoi. Czyje to zwłoki? Co to za pokraka? Ale z ciebie oferma! Ty matpo! Nie badź świnia! Zawołaj kelnera! Kierowca nie może prowadzić po alkoholu. Każdy jest kowalem swojego losu. Przyszła jakaś ofiara. Ktoś na ciebie czeka. Chcę rozmawiać z kierownikiem. Jestem naukowcem. Trup ścieli się gęsto.

W liczbie mnogiej związek rodzaju i płci jest jeszcze bardziej złożony niż w pojedynczej. Przede wszystkim występują w niej tylko dwa rodzaje: męskoosobowy i niemęskoosobowy. Ten pierwszy ujawnia się morfosyntaktycznie na trzy sposoby: 1) przez końcówkę przymiotnika lub zaimka w mianowniku (-i/-y wobec -e: tadni, wielcy, ci/ladne, wielkie, te). W innych przypadkach końcówki są jednakowe i opozycja jest zneutralizowana. 2) zakończenie -li w czasie przeszłym i trybie przypuszczającym. 3) biernik równy dopełniaczowi. Użycie rodzaju męskoosobowego normalnie oznacza, że w grupie osób, o których mowa, jest przynajmniej jeden mężczyzna. A więc zdanie Wypisano wszystkich pacjentów sugeruje, że chodzi o grupę płciowo mieszaną, w której przynajmniej jedna osoba była płci męskiej. Gdyby były to same kobiety, powiedziałoby się w zasadzie Wypisano wszystkie pacjent$k i$. Jednak nie jest tak do końca. Można powiedzieć, i często tak się mówi, np. Odwołałem zajęcia, bo studenci nie przyszli, nawet jeśli w grupie są same studentki.

Kategoria rodzaju męskoosobowego stanowi skądinąd tak skomplikowany problem, że jest tematem przynajmniej na osobny artykuł. Z tego powodu w tej pracy omówimy tylko kilka najistotniejszych kwestii. A więc zasadniczo użycie rodzaju męskoosobowego występuje, gdy w omawianej grupie jest przynajmniej jeden mężczyzna. Mogą to być sami mężczyźni, jak w zda- 
niu Moi bracia już się wyprowadzili. Wskazuje na to semantyka rzeczownika bracia użytego w jego pierwszym znaczeniu biologicznego pokrewieństwa. Jednak już w sformułowaniu starsi bracia $w$ wierze chodzi niewątpliwie również o kobiety. W zwykłym użyciu rzeczowniki typu klienci, pacjenci, sprzedawcy, uczniowie, Rosjanie, wierni, zakładnicy, urzędnicy, sprzedawcy, widzowie oznaczaja grupy płciowo mieszane i tylko, w bardzo szczególnych przypadkach, samych mężczyzn lub same kobiety. A w użyciu generycznym, zawsze grupy mieszane. Odpowiedników żeńskich w liczbie mnogiej używa się w tej klasie rzeczowników tylko wtedy, gdy w sposób oczywisty chodzi wyłącznie o kobiety, np. wszystkie pacjentki w ciaży albo wszystkie uczennice żeńskiego liceum, albo fakt, że są to same kobiety jest jakoś relewantny, np. w zdaniu Mimo że do niektórych pracowników mam zastrzeżenia, wszystkie moje pracownice sq doskonałe.

Niektóre rzeczowniki, w liczbie mnogiej męskoosobowe, nie mają żeńskich odpowiedników. Są to np. goście, widzowie; nie ma w nich zatem możliwości zakomunikowania, za pomocą środków gramatycznych, że chodzi o same kobiety, jeżeli akurat występuje taka sytuacja.

Sa jeszcze przypadki używania rodzaju męskoosobowego, choć wiadomo, że w grupie nie ma żadnego mężczyzny, np. w zdaniu Alicja i Pikuś byli na spacerze, w którym Pikuś jest psem Alicji.

Wreszcie, przynależność do rodzaju męskoosobowego jest stopniowalna. Istnieje bowiem grupa rzeczowników, które stosują tylko jeden wykładnik męskoosobowości (biernik równy dopełniaczowi), a z punktu widzenia pozostałych dwóch wykładników są niemęskoosobowe. Są to rzeczowniki typu dranie, grubasy, chłopy. Mówi się Te dranie / grubasy / chłopy były zmęczone, ale Widziałem tych drani / grubasów / chłopów.

A zatem, użycie rodzaju męskoosobowego znaczy tylko tyle, że jest bardzo wysokie prawdopodobieństwo, że w grupie określanych osób jest przynajmniej jeden mężczyzna ${ }^{7}$. Użycie rodzaju niemęskoosobowego nie przesądza przy tym, że w opisywanej grupie nie ma mężczyzn. Pewne rzeczowniki bowiem, choć odnoszą się do mężczyzn, są niemęskoosobowe, jak karty, trupy; inne są męskoosobowe częściowo, tylko wg jednego kryterium jak szkopy, dranie, żabojady. A więc, użycie formy niemęskoosobowej oznacza tylko

\footnotetext{
7 Zauważmy, że męskoosobowy jest rzeczownik diabli, a niemęskoosobowy krasnoludki.
} 
znacznie zwiększone prawdopodobieństwo, że w opisywanej grupie osób nie ma mężczyzny.

Podsumowując: płeć nie jest kategorią gramatyczną rzeczowników; kategorią jest w nich rodzaj, silnie związany, ale nie tożsamy z płcią.

Kategoria płci jest natomiast w języku polskim kategorią zaimków osobowych pierwszej i w mniejszym stopniu drugiej osoby, a także odnoszących się do nich czasowników i orzeczników oraz - w jednym szczególnym przypadku - zaimków dzierżawczych trzeciej osoby. W kategorii tej stosowane są te same wykładniki, co w kategorii rodzaju, jednak z absolutną konsekwencją: męskie lub męskoosobowe dla osób płci męskiej, żeńskie lub niemęskoosobowe dla osób płci żeńskiej. Kategoria płci ujawnia się wyraźnie wtedy, gdy występuje konflikt między płcią a rodzajem.

Kategoria płci nie występuje zasadniczo w trzeciej osobie liczby pojedynczej, gdyż istniejące składniowe uzgodnienia odnoszą się do rodzaju. A więc: Ten babsztyl byt wstrętny. Co tu robiła ta ciota? Wyjątkiem są odnoszące się do wymienianych osób zaimki dzierżawcze oraz zaimki anaforyczne: Nie podoba mi się ten babsztyl, jej maniery sq okropne i nie powinna tyle gadać; co ona tu w ogóle robi? Ta ciota mnie wkurza, nie mógtby się on stad wynieśćc Niemniej w tych przypadkach zmiana kategorii rodzaju na kategorię płci nie jest obowiązkowa, zdarzają się użycia z konsekwentnym utrzymaniem wszystkich uzgodnień rodzajowych. Obowiązkowa jest natomiast w odniesieniu do zaimków dzierżawczych w takich rzeczownikach jak ekscelencja, wysokość. Używa się zawsze jego, gdy chodzi o mężczyznę i jej - gdy o kobietę. Jednak gdy chodzi o łączliwość tych rzeczowników z czasownikami i orzecznikami sprawa już nie jest tak oczywista. Jest wprawdzie norma, która wskazuje, że należy mówić Jego ekscelencja byt głodny, ale jest to norma arbitralna, nie do końca zgodna z systemem i intuicją użytkowników. Każdy, kto musiał sformułować podobne zdanie, na pewno przynajmniej przez chwilę się zastanawiał, jakiej formy użyć.

W drugiej osobie liczby pojedynczej kategoria płci jest bardziej wyrazista. Przede wszystkim wyeliminowany jest w niej rodzaj nijaki, zastąpiony przez kategorię płci: Co robiłeś/robiłaś, dziecko? ${ }^{8}$. W czasowniku i orzecz-

${ }^{8}$ Zdanie Co robiłoś, dziecko jest wprawdzie systemowo możliwe, ale może być użyte tylko jako szczególny środek literackiej ekspresji. Zob. na ten temat: Łaziński (2006: 191). 
niku częściej niż w trzeciej osobie następuje uzgodnienie do płci, nie do rodzaju: Chciałeś czegoś, cioto jedna? Cześć, babsztylu, wkurzona jesteś? Choć ciągle jeszcze możliwe jest użycie form zgodnych z rodzajem, z wyraźną konotacją stylistyczną.

Konsekwentnie kategoria płci występuje w pierwszej osobie liczby pojedynczej. Jest to więc kategoria zaimka ja, której wykładniki pojawiają się w czasowniku i w przymiotnikowym orzeczniku. Jej funkcjonowanie jest bardzo proste. Osoba płci męskiej używa form męskich, osoba płci żeńskiej - żeńskich: bytem gotów / bytam gotowa. Oczywiście nie chodzi o płeć zgodną z kariotypem, ale płeć, z którą nadawca komunikatu się identyfikuje. Odstępstwa są oczywiście możliwe, ale jedynie w celach artystycznych, dla żartu itp.

Sprawa komplikuje się w liczbie mnogiej. W trzeciej osobie występuje konsekwentnie kategoria rodzaju, powiązana z płcią w sposób, jak pokazaliśmy, bardzo złożony. Rodzaj niektórych konstrukcji nie jest przy tym oczywisty. Pytanie: czy ich ekscelencje byty czy byli? Rodzimi użytkownicy nie mają w tej kwestii po prostu wyczucia.

W drugiej osobie obserwujemy dużo uzgodnień do płci, nie do rodzaju. Np. często się mówi Co robiliście, drogie dzieci?, choć forma na -ły-też jest możliwa, niezależnie od składu płci w danej grupie dzieci. Prawie zawsze kategoria rodzaju jest zastępowana przez kategorię płci w klasie typu chamy, dranie, grubasy, np. No to się, chamy, doigraliście (choć w trzeciej osobie jest chamy się doigraty).

W pierwszej osobie liczby mnogiej mamy sytuację zasadniczo inną niż w pojedynczej. Przede wszystkim my nie jest zwykłą liczbą mnogą od ja, bo $m y$ nie równa się ja $+j a$, jako że nie mówi się chórem. My to zawsze ja $+k t o s ́$ jeszcze. Nadawa komunikatu mówi zatem zawsze w imieniu jakiejś grupy. Grupa może być jednorodna lub mieszana płciowo. Jeżeli nadawcąjest kobieta, użyje form rodzajowych albo męskich, albo żeńskich. W pierwszym przypadku istnieje supozycja, że w grupie jest przynajmniej jeden mężczyzna, choć nie jest tak zawsze. W grupie może być np. pies albo same kobiety, przy czym nadawczyni komunikatu nie zwróciła na to uwagi. W drugim przypadku mówiącym jest kobieta, która chce zakomunikować, że mówi w imieniu grupy, w której są wyłącznie kobiety. Mężczyzna natomiast w normalnej sytuacji, używając pierwszej osoby liczby mnogiej, posłuży się zawsze formą męskoosobową. 
A zatem, w języku polskim istnieją kategorie zarówno rodzaju, jak i płci, zwykle powiązane ze sobą, ale czasem tworzące opozycję. Zasadnicza różnica polega na tym, że kategoria rodzaju jest kategorią rzeczownika i przymiotnika, a kategoria płci zaimka osobowego, przede wszystkim pierwszej, w mniejszym stopniu drugiej, jeszcze rzadziej trzeciej osoby.

Jednocześnie wykładniki rodzaju znajdują odzwierciedlenie w formach paradygmatycznych rzeczowników i przymiotników, podczas gdy wykładniki płci ujawniają się w czasownikach i orzecznikach, stanowiąc przykład morfemów nie na swoim miejscu.

\section{Bibliografia}

Bańczerowski J., Pogonowski J., ZgóŁka T., 1982, Wstęp do językoznawstwa, Poznań: Wydawnictwo Naukowe UAM.

Burgos Echagüe J., 2012, Lingüísitca contrastive vasco española, Cuadernos Cervantes, Época II.

KozIARSKi M., KrysiaK A.P., 2012, Rodzaj gramatyczny rzeczownika jako nośnik informacji pozagramatycznej I. Przegląd literatury dotyczącej rodzaju gramatycznego, Investigationes Linguisticae XXVI, s. 20-38, [on-line], http://www.staff. amu.edu.pl/ inveling/pdf/Koziarski-26.pdf, [7.10.2014].

KuCAŁA M., 1978, Rodzaj gramatyczny w historii polszczyzny, Wrocław: Zakład Narodowy im. Ossolińskich.

Laskowski R., 1999, Rodzaj gramatyczny, w: R. Grzegorczykowa, R. Laskowski, H. Wróbel (red.), Gramatyka wspótczesnego języka polskiego. Morfologia, wyd. 3 poprawione, Warszawa: Wydawnictwo Naukowe PWN, s. 207-213.

ŁaZIŃSki M., 2006, O panach i paniach. Polskie rzeczowniki tytularne i ich asymetria rodzajowo-ptciowa, Warszawa: Wydawnictwo Naukowe PWN.

MańczaK W., 1956, Ile rodzajów jest w polskim?, Język Polski XXXVI, z. 2, s. 116-121.

Markowski A. (red.), 2012, Wielki stownik poprawnej polszczyzny, Warszawa: Wydawnictwo Naukowe PWN.

Nowosad-Bakalarczyk M., 2009, Pteć a rodzaj gramatyczny we współczesnej polszczyźnie, Lublin: Wydawnictwo UMCS.

Pycia P., 2011, Płeć a język, Katowice: Uniwersytet Śląski, Wydawnictwo Gnome.

SALONi Z., 1976, Kategoria rodzaju we współczesnym języku polskim, w: R. Laskowski (red.), Kategorie gramatyczne grup imiennych w języku polskim, Wrocław: Zakład Narodowy im. Ossolińskich, s. 43-78.

SAloni Z., 1988, O tzw. formach nieosobowych męskoosobowych w polszczyźnie, Biuletyn Polskiego Towarzystwa Językoznawczego XLI, s. 155-166. 
STEFAŃcZyK W. T., 2007, Kategoria rodzaju i przypadka polskiego rzeczownika, Kraków: Wydawnictwo Uniwersytetu Jagiellońskiego.

URBAŃcZYK S. (red.), 1991, Encyklopedia języka polskiego, Wrocław: Zakład Narodowy im. Ossolińskich.

ZARon Z., 2001, Jeszcze o kategorii rodzaju. Podstawy charakterystyki gramatycznej, w: W. Gruszczyński (red.), Nie bez znaczenia... Prace ofiarowane Profesorowi Zygmuntowi Saloniemu z okazji jubileuszu 15000 dni pracy naukowej, Białystok: Wydawnictwo Uniwersytetu w Białymstoku, s. 329-341.

ZARON Z., 2004, Aspekty funkcjonalne polskiej kategorii rodzaju. Charakterystyka fleksyjna, Warszawa-Puńsk: Wydawnictwo Aušra.

\section{The Category of Gender in Polish}

\section{( s u m m a r y)}

The article aims at presenting the opinion that, in the Polish language, apart from the grammatical category of gender, there is also the grammatical category of sex. The two categories are usually related, sometimes, however, they formulate an opposition. The category of gender is a category of noun and adjective, while the category of sex refers to personal pronouns, mostly to the first person singular, less frequently to the second person singular and even less often to the third person singular. Exponents of gender are mirrored in the paradigmatic forms of nouns and adjectives, whereas the exponents of sex reveal themselves in verbs and predicates, being examples of misplaced morphemes. 
